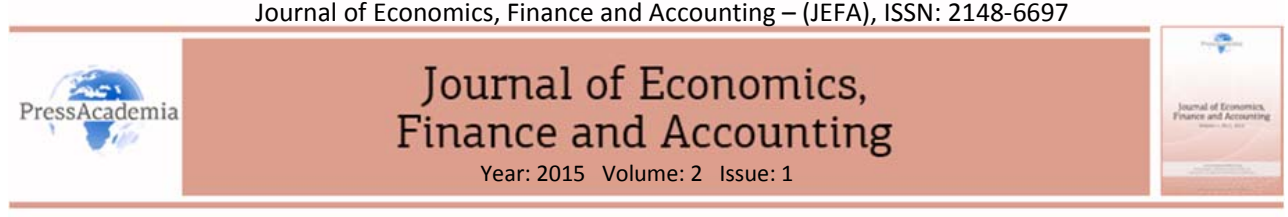

\title{
FINAL VERSION OF CAPITALIZM: ECONOMIC INTELLIGENCE IN KNOWLEDGE ECONOMY
}

\section{DOI: 10.17261/Pressacademia.201519781}

\section{Ceyhun Haydaroglu ${ }^{1}$}

${ }^{1}$ Bilecik Seyh Edebali University, ceyhun.haydaroglu@bilecik.edu.tr

\begin{tabular}{|c|c|}
\hline Keywords & ABSTRACT \\
\hline $\begin{array}{l}\text { Industrial economy, } \\
\text { knowledge economy, } \\
\text { economic intelligence. }\end{array}$ & $\begin{array}{l}\text { Today's advanced economies which became a knowledge economy have } \\
\text { witnessed to important structural variations since the recent past and } \\
\text { pioneer sectors of economic activities create basic characteristics of this } \\
\text { change. In this process, industrial economy based on natural resources } \\
\text { and labor force has switched over agricultural economy accepted as a } \\
\text { main production factor and knowledge based economy has taken its } \\
\text { place by means of becoming knowledge a major factor among } \\
\text { production factors. Knowledge based economy described as modern } \\
\text { economy or new economy has centralized human and technology over } \\
\text { economic development. Correspondingly, it is accepted as that an } \\
\text { economic development is provided with some factors such as database, } \\
\text { use of technology and adequate humane capital accumulation. High } \\
\text { incomes which will lead enterprises such as minimizing production } \\
\text { expenditure with new inventions in industrial fields, using new } \\
\text { technologies at production field and first releasing to the market of } \\
\text { some technological devices have confronted as a indicator in which how } \\
\text { important economical intelligences are. Within this context, reflecting } \\
\text { latest outlook of capitalism in change and transformation economy it is }\end{array}$ \\
\hline $\begin{array}{l}\text { JEL Classification } \\
011,031,034\end{array}$ & $\begin{array}{l}\text { tried to figure out under the roof of economical intelligence in } \\
\text { knowledge economy which come out as a new threat and threat } \\
\text { perceptions. }\end{array}$ \\
\hline
\end{tabular}

\section{INTRODUCTION}

Industrial Revolution which exists from discovery of steam economy has become a main stone which accelerate the period of change beginning with Mercantilism. Becoming a current issue of new formations with corruption in traditional community structure has whet with Industrial Revolution. New frameworks have come up in economic, social, political and cultural fields. The main characteristic of whole changes in socioeconomic system is appearance with extroversive worldview. People have head towards other countries to meet their needs and sell their goods; looked for ways to communicate with other people or territories; had a voice on governance with growing conception of democracy and new point of views, polyphony, polychromy have become a current issue. 
Along with going beyond traditional society in this way and emerging a new community structure. The Industrial Revolution which is the main variable directing new structure have led to called as a industrial society which gets new identity.

After the second world war, especially it the effects of changes in 1980's social system has begun to take new form. In the essence of this change, computer and communication technology have a big role. Production of new information, method and technologies and becoming popular with getting easy of transferring have a directive function in occurring metamorphosis in low grade of social system. A good number of changes drew attentions like appearing of new products, new sectors, new economic policies, seeking for reconciliation among social classes, participation to governance from different classes and becoming prominent of humanistic values and time. Changing countenance of industrial society with the effect of becoming permanent of this new community structure, knowledge production and transmission has been named with concept of knowledge society.

There have been some economic, social and political conversions in transmission to knowledge society from industrial society. While economic developments could be stable and foreseeable in industrial economy, economical structure is very dynamic, complicated and unforeseeable in knowledge economy. Because of these characteristic developed countries give great importance to advanced technological field which have the advantage of competitive force. Economy which is the economic structure of knowledge society in which humane and individual preference come into prominence is under the customer guidance. While great industrial companies are propellant power in industrial economy, knowledge based houses that adopt marketing conditions quickly aim global marketing, also more dynamic in knowledge economy and reformist and entrepreneur stand out. While competition firstly takes place locally in industrial economy, powerful global values series involve company, product ecosystem and global fierce competition. The keys of being successful in competition are being fast, changing and composing powerful companies and product ecosystems.

Competition in knowledge society means competing by producing reforms and competition in process of globalization in whole world. Competition atmosphere growing with globalization and rising importance of knowledge for produce has increased the attempts to steal business secrets. Developing countries have begun to make effort to get industrial information of successful developed countries and developed countries have begun to make effort to protect this information and to sell these goods by which they get through these information in new markets. Because they do not have sufficient financial resources and they are not able to invent something new successful countries of third world increased their attempts to steal technological, scientific and commercial secrets. This situation has revealed to look for new field of occupation for intelligence service of all countries. 


\section{TRANSMISSION TO INDUSTRIAL SOCIETY FROM KNOWLEDGE SOCIETY}

There have been important facts of technological innovations in change of societies. Technological innovations have changed and converted economic and social structures of societies by time.

Some technological innovations are more effective than others and these have change covered in economic and social life. It could be mentioned that there are three society stages which changed history of humanity and accepted as begin with improving plow, steam engine and first modern computer (Aktan and Tunç, 1998:118). Agricultural society in which marketing is restricted with close villages accepted as begin with invention of plow and accepted as humanity went by permanent settlement from migrant settlement is the first stage. Industrial society which begins with invention of steam engine and becoming important to specialized in work and mass producing also modernization process impressed by French enlightenment in economic, social and cultural whole fields and accessibly of markets in everywhere by physically is the second stage. Third stage is knowledge society which beings with first digital computer, focused on qualification person and information and resources in which accessibly with digital communication webs (Basalla, 2014:284).

New society structure which come up with Industrial Revaluation differ from atmosphere in which producing is made by primitive methods, main economical occupation is agricultural and have major self-consumption that we call traditional society. New qualities have prominent such as the share of fact of production in production, production style, product quantity and product range. Technological improvement originated from science and adopted to industry namely invention of steam engine has taken place (Braudel, 1991:112).

Contrary to traditional society, capital step forward in industrial society rather than weight factors of production. Labor factor relatively loosed its importance in tandem differences in production method. Machine took place instead of physical labor and work. The place of labor factor in production process have evaluated with interaction with capital. Thusly, capital has become a factor which increases the productivity of labor. Entrepreneur of industrial society have qualification that maintain economic activity with motive of increasing profit. Therefore, he has struggled to get benefit of labor of capital as far as possible. Interactions which increase with usage of capital has gained importance. In traditional society, people try to adopt natural have fronted to change and control natural through several conversion of industrial society. Recognizing that capital effects the spoil of natural atmosphere (Toffler, 1992:26).

The needs of industrial society have been further physical need and while producing is being canalized that prominent sectors have been in that form. In the process of industrial society in which human needs like sheltering, clothing and nutrition are preferential enhancement of output has been provided with the opportunity of mechanization (Drucker, 1994:66). 
That structure which occurs in the first process of industrial society is not unchangeable. Improvements in science and technology have caused form and content changes in social structure permanently. Specially as part of faster improvements after II. World War, industrial civilization has begun to wrap up quite different qualities from the point of weight of producing factor, producing styles and sectoral settlement.

Within this context in which faster changes occur much has wrap up new form, gained insights and appeared new concepts. In this new concept, individual, company and state have differentiated finally. In this differentiation, effect of science and technology is more powerful and clear. Now, there has been and dominance of knowledge as a main producing process occur in the manner of increasing of fertility, more share of producing and increasing of life quality of human.

In new period, in the direction of improvements in computer and communication the form of changes based upon knowledge on producing factors is the main factor of increasing of social welfare in knowledge society. Knowledge which focus on knowledge for giving it to humanity as a means of service in whole areas of life with opportunities that provided by knowledge and communication technologies (Denning and Durham, 2001:24).

The main variable which effect the producing process in the manner of quantity and quality is knowledge in the knowledge society, Knowledge create the base of improvement in producing new product, new business model and new methods. Coming up produced products, developing new management mentality and new point of views actualize in relation to get what kind of knowledge and how used. Thus, knowledge is the main factor to produce new products and ideas. However, amount and quality of information had better not to be considered as only variable. Interactions among variables in knowledge society have a great effect on creating results. In this respect, the effect of knowledge on other producing factors should not be disregarded (Stevenson, 2003:10).

Interaction of labor with knowledge has revived consideration of labor in qualities extent. As a result of globalization trend, the potential of labor had better deal with educational policy. Now, it is essential to take aim of person who is not only capable of employable but also can comprehend why and how world changes and have advanced ethical approach and cultural awareness. Creating high quality labor means creating individual who has good knowledge capacity and is in interaction with computer and communication, not disconnected with scientific and technological improvements to assure this knowledge.

To take place of individuals who have advanced knowledge background create the entrepreneur who has modern point of view to take steps in sense of entrepreneurship. Regardless, rather than profit motive entrepreneur prototype who has motive of respect for human and natural habitat and has the capacity of using rationalist methods tousle other resources. On the other hand, capital has been used computer aided and has a quality of more productive, faster and flexible when used with specialized and trained labor. Adopting nature in agricultural society and controlling nature in industrial society have appeared as overcoming nature in knowledge society, in this manner new technology and products have been improved. 
Beyond industrial society, human's need have been appreciated as social, intellectual and emotional rather than physiological. Wishing communicate with other people have revealed several tendencies like creating more leisure time, having time for cultural values like cinema, theatre and music and having better educational background. Paralleling that, rising sectors have changed in economical fields. Human based institution and sectors have come into prominence like educational establishment, research center, insurance bank, healthcare organization and social service centers. On the other hand, services sectors integrated with information technology lead flexible production unique to individual and increasing service speed. Now, rather than mass production regardless of quantity and quality of need individual based production mission has gained importance.

\section{KNOWLEDGE ECONOMY AND ITS EFFECTS}

Knowledge society concept in a consequence of knowledge based economy was attributed meaning including social upheaval as well social revolution. Correspondingly, new society, based service sectors, took the place of predominant industrial society (Kaymas, 2010:67). In globalizing society, knowledge became productivity tool for global competition after industry (Kuhn, 2007:34). From this aspect, knowledge society could be described as production of all kinds of information, access to all information networks, increase of sharing current information, get easy to information propagation and become active of information in all sectors (Kutlu, 2005:89).

Substantially, economic systems based on knowledge have major impotence among producing factors and economical order is named as knowledge economy. In knowledge economy speed economy took the place of scale economy and there has been competition density (Bayram, 2010:66). While in knowledge economy knowledge and labor force are the most important sources, in new economic order producing knowledge and mentioned to trade reduced wealth and prosperity as main determiners (Aktan and Vural, 2004:150).

Knowledge economy, new financial paradigm, is the main parameter which is the tangible and measurable at the same time. Paradigm change occurs as a result of non-physical inputs (information, content, process, social fund, intellectual production) placing inputs (feedstock's, labor cost, machine, buying power) Information create value only when producing, sharing and circulation are integrated globally, non-stop and fast, in a word administrated synchronously on concurring webs (Rifkin, 2000:36).

Information walks around global networks. However, taking over information for creating optimal added value is a stratified process which range from partnership of companies or other cooperation platforms to local or regional development projects to network management of national macro scales. Sustainable development acceleration depends on knowledge economy which integrates social mechanism and culture and developing national politics which aim to transmission to knowledge society. National benefits pass by producing, processing, recycling, reaching, sharing and managing information, in other words being global player. 
Improvements in information technologies lead to paradigm chance in economical mechanism and cause to change rules of economic process and economical activities towards policy makers and market actors (Smith, 2000:2).

The best example could be indicated in which new society based on different paradigm as gaining importance information production by coming into prominence of different symbolic elements and going away factory and material production from quantity of main opponent of society (Kutlu, 2000:163). Transformation in economic structure lead characteristic of social structure to change at the same time. In this way, it could be said that human intelligence has gained power with information technologies as well as industrial revolution added power to human. Consequently, paralleling to get more complicated condition of economic structure there has been increase in labor demand which can be described as information workers (Splichal, 1994:59).

In the way to information technology, the development process of information and communication technologies are observed with two common characteristically facts in global dimensions. These are explained as getting decentralist relating to exceeding or removing usage of contents of technologies. The result of this technological development has led to social changes in different levels (Ogan, 2007:17). Developments in information and communication technologies made communication process of human more active by supplying the opportunity to more people to communicate in bigger societies. This technology which constitutes transmission among various grades of different society or societies will lead to increase of social development, integration and demonstration (Jefress, 2007:136).

Information which become a product has led to get rich and have prosperity of society and increase of productivity by forming positive externals in different areas of society. Knowledge which become ageless by using an even a resource that renew itself has changed the direction of productivities which are main stones of economy and information and so led production to become sustainable in long term. Beside there have been social changes because of developments of information and communication technologies there have been new tendencies to use of new methods in working processes (Özsağır, 2007:144).

In economy which globalizes with the effect of developments information and communication technologies producers can find opportunity to have produce in the most advantageous places for themselves. Competitive dynamics in economy have gotten strong of information's by getting easily transmissible by current communication technologies. In this manner, an important stable resource of competition advantage of the capital investment relating to production process and service presentation is a current human capital accumulation of nation which could be transferred internationally.

\section{COMPETITION UNDERSTANDING OF KNOWLEDGE SOCIETY}

There has been such a social structure that everything has changed very fast and continuously. The main factors of this are technological developments. In this new 
construct in which computer and information technologies direct several micro and macro topic has engaged and affected each other.

Competition expanded global level beginning from self-development of individual and changed contexts. The competition understanding of knowledge society is oriented at study and competition power will be gotten at the end of the study. The study aims for producing innovation. To produce innovation it is necessary to be creative. And creativeness has been firstly individual order and then social, organization and institution level which is constituted by individuals. It is depended on not only creativeness capacity among individuals but also competition understanding among institutions and societies. It is the point in question that there have been economic, political and socio-cultural activities or effects to occur in worldwide. Evolution qualified as globalization demonstrates the other quality of competition. From now on, competition is a question for whole world. It has changed not only the current region but also the conditions of whole world. The obligator to have competition power has been carried to other extent. To become limitless and to spread whole world of liberalization have revived more powerful equipment on the face of such as widespread structure (Leung, 2004:27).

One of the stages of competition idea in knowledge economy is competing of individual or companies with themselves and getting more forward of its consequences. This understanding which can be explained as supra-competitive understanding which will reveal competition by exceeding itself of economical entity is in the direction of being more different of products or innovations will be revealed by expansion to whole entities. Entities that continuously focused on developing itself struggle for not to fall behind and as a result struggle of whole entities has influence on consumers, workers and whole social systems. Because of disappearing of orders in knowledge economy it is obligatory to prove innovative products and services which can compete with global companies to exist in local markets (Eliason, 2005:443). Economical structure in knowledge economy has evolved a structure that reply to demand, distributed proactively, technological integrations and commercial cooperation which have mutual dependency from a structure that has vertical integration, internal talents, internal AR-GE, internal projects and internal substructure (Barnett, 2006:90). Therefore, competition in knowledge economy has evolved different directions.

Competition policy in knowledge economy requires to develop dynamic competition quality to contain high technology industry networks (Clarke, 2003:25). Industries like software, biotechnology and nanotechnology central on knowledge economy have supplying qualities among components of ecosystem as well as there has been intensive proactively competitive environment (Stigltz, 1999:1).

Monopolies, patent systems to create protection for intellectual property right and judicial and technical outline to apply could cause missing competition. There has been missing competition in the nature of knowledge economy because of reasons like copyright and patents of intellectual property right. Instead of full and decreasing yield in classic economy missing competition and increasing yield come into prominence in knowledge economy. High technology industries which have intensive information content generally 
operate in monopoly conditions. The monopolies in these industries could show the natural monopoly qualities.

Generally, in industries which adapt to increasing yields in terms of scales in the event that decreasing prime cost of the same product requires limited companies could lead to appear natural monopolies (Söylemez, 2006:18). Missing competition in knowledge economy is a result of AR-GE activity and proactivity. Rights to be monopoly for specific periods have been given to innovative companies by patent systems. Because innovating technologies could ensure to be monopoly for companies for given period due to these technologies it could cause missing competition.

Knowledge asymmetry based on knowledge economy has been accepted as a main factor of competition environments. Many software companies struggle to change their products with new versions. Proactivity for software companies is the most important tool to protect their market dominance in work ecosystem. Profitableness of companies has been protected due to knowledge asymmetry which come from that their technologies are not familiar to competitor and customer and missing competition which is affected by that situation (Clarke, 2003:26).

Superiority in knowledge economy is based on guidance superiority of knowledge on a large scale. Circulation of knowledge which become the most important input of production determines medium of changes like international relations, politics and media as well as economy. Societies which manage global information circulation manage international networks as well. Technology production is just a component of this process.

The countries need to rename themselves because of the developments in different areas such as economy, community and politic. The countries' dynamics occur when they are classified as the developed, developing and late developer. In recent years, it is pointed out that different aspects occur in the transitions from production, the key word of the industrial society, to the terms like information and communication technology. As well as these developments, the competing market conditions, competition and economy vary and it has a great importance to compare the countries. On the other hand, a meaningful dynamism in the national changes has been experienced in recent years. Although some sectors lose their importance, the new sectors appear for the purpose of high profitability and these sectors spread out on the international stage and change the common extensions of economy and competition. While the previous sectors lose their competition areas, profitability and the number of the employees, the new ones that are open to technological developments become attractive, create their own business opportunity and lead to increase the number of the employees. Besides, the common use of the internet, telecommunication and information technology brings a new perspective to activism, effectiveness, and productivity, input-output, the service delivery, quality and profitability. So, the mentioned technologies make inquiries for the basic foundations of classical technology. In addition to these developments, a lot of new sectors, especially communication and information sectors, keep the leading position and have a role in new economy variables because of the prominent globalization. 


\section{ECONOMIC INTELLIGENCE}

By the 21st century, the economy has been the main reason of the wars, but the armies are militant. However, especially after the Industrial Revolution, the companies' fund and multinationality have become important for the states' foreign policy. Therefore, the term "intelligence" that is important for the states and the armies has also become important for the companies and economy. Due to the changing nature of the wars, the states have preferred the economic warfare, not the military attack. From this point, intelligence collection has become one of the strategies of the century to damage any states' or companies' economy.

Today, the term "economic intelligence" is used for different two purposes. The first purpose of the countries is to look after their own benefits, follow the other countries' economic activities to enhance the quality of life and to support the companies to have the right to comment on global economic marketing by evaluating the information. The second one is to get information to increase the local, regional or international companies' market share in their activity areas, to make new investments, to experience different markets, to renew and improve production process (Porteous, 1995:17).

Potter defines the economic intelligence is any intelligence that helps competitive economy. Financial and commercial information's, the government and the company information can be evaluated as the information that will affect the investment decisions and risk the relations among the states.

The profit of economic intelligence and the profit of foreign concerns that get from these information's could create economic disadvantage in economy. Economical intelligence activities will be a subject that concern security when it jeopardize employment, research and development investment relative productivity and therefore to act without intelligence organization is not mostly possible (Potter, 1998:7).

Economical intelligence could be resumed that it is supposed to contain every kind of information related to fields of economy. Therefore economical intelligence contain fields related to national economy such as economical geography, transportation, natural and human resources and science and technology (Williams, 1954:12). Mostly, economical intelligence is named with different names and even mistaken by cognitively. For the use of integrity of subject it is better to include these terms.

It could be said that economic espionage has taken a part united. Economic espionage could be mentioned as gathering of economic data belong to a nation from another nation and the thieving of private information (Nasheri, 2005:16). Economic espionage is having an secret or illegal attempt to sabotaging and preventing another country's economic security that they get economical intelligences (Potter, 1998:7).

Industrial espionage: the main difference between industrial espionage and economic espionage is the efforts of state to get information (Naheri, 2005:12). Industrial espionage could be defined as activities done within the knowledge and supports of states by companies or organizations that have juristic personalities. 
Technological espionage: Technological espionage and scientific espionage could be said that they have cause and effect relation. Technological espionage is defined as attempts to get technological development programmers belong to critic industries like electronic, space, defense and biotechnology (Nasheri, 2005:15).

Activity field of scientific espionage contains areas like laboratory and AR-GE departments. All stage of process of getting scientific information could become a espionage matter. Revolutionary information which will be gotten will bring forward the one in competition. Also it will bring great economical advantage and benefit (Akar, 2005:83).

It could be said that producing information with globalization and getting commercial value of produced information have gained importance. Therefore, the contributions of developments in scientific and technological fields cannot be underestimated.

\section{ECONOMIC INTELLIGENCE AND STATES}

It had been observed that commercial activities increased among societies with evolution of feudal societies and there had been wars because of economic interests. Relations between kingdoms and continents which occur with uniting of societies have begun not only with wars but also with economic relations. To have economical income tools like fertile lands, metals and spices and to begin commercial activities by changing these have provided to occur economical terms like money, interest and dept.

The first samples go too back because economical intelligence term is a term which emerge with the beginning of change economy. However, the first known example is about privacy of silk producer 1500 years ago. Even there have been different expressions, Chinese princess had an attempt to cause resolution of silk production which is made secretly and gave silk warm by hiding it in her hat to Khotan, Indian prince, whom she will get married. So, silk warm production secret was solved and production passed to the West (Yıldızhan, 2005:19).

With the increase of geographical discoveries with transoceanic travels, commercial relations of societies in different continents began to develop. It could be said that exploration of new places ensured to beginning of industrial espionage systems. As a proof, a law of Venice Republic in 1474 could be displayed. Venetian leaders understood that new technologies had been developed by other civilizations in worlds and these had not been in Venice yet. If entrepreneur Venetian could be encouraged to travel around world and bring explorations Venice would be successful. To improve this espionage Venice made a monopoly law to prize adventurer, according to that law, if somebody bring a machine or method from somewhere else only this man would use this machine or it could be used by this man for couple years in Venice orders and other could not make use of it. In this manner, this man would be successful and Venice would get new technology (Nasheri, 2005:12).

By this way, it could be mentioned that patent and copyright term were created and linked a law. Venetians began to outclass other Mediterranean city-states with this technic. Over time similar laws were made by France, Germany and England. 
China lost another secret because of economic espionage in 18th century. After China spent centuries to produce high-quality porcelain known only by their chemist a French called Jesuit visited China Kingdom porcelain factory. All secrets were shown to him about porcelain production in this visit. French told all details of porcelain production to France with his letter (Ĕ̆ri, 2012:412).

The importance of economic intelligence was understood with sending William Carmichael to investigate economical activities of developing countries like effect of tobacco production of Ukraine, a state of Russian Kingdom, on foreign countries in Europe.

In his secret correspondence with the aim of inform his uppers he indicated to retain that Ukraine had a capacity to fulfill tobacco need of whole Europe but despite that fear he gave good news that the best thing he saw was the best Ukraine tobacco was worse than the worst American tobacco (Manning, 2006:42). This activity of American intelligence could be regards a first economic intelligence activity in which period's world trade began to develop.

In his book, war with other techniques: Economic intelligence in America, John Fielka (1997) mentioned about a man named Francais Cabot who bring secrets of weaving look after a visit to Great Britain in 1811. By revolutionizing in textile industries in New England it had been indicator to development of technological thieveries with technological changes from these years (Nasheri, 2005:12).

It has been seen that new industrial equipment were captured finding new production methods were used by different countries and stock market was carried out to use in speculation in first activity times. Ventures who are in service of stock market and capital markets carry interest by using various components of economic intelligence through speculative processes.

One of the best institutions in specific intelligence is private bank institution of Nothan Rotschild. This institution gave great importance to have detailed information about customers when they open a credit and succeeded with these successful intelligence working. In 1815, the result of Waterloo war could not be learned yet, Rotschild received news that Prussians and English defeated Napoleon and released official equity security by evaluating in a good way. Other banks and companies that knew Rotschild had sound news pushed off official equity security with lower price believing equity security will decrease. In a short time, Rotschild picked up whole securities and had got a huge fortune (Avcl, 2004:35).

When we analyze economical attack history, one of the riveting examples is destroying Japanese agriculture due to intelligence activity of America toward Japan. This success belongs to Dr. Robert Strausz Hope who had been a ambassador in Turkey in past. Huge who study on Japanese detected that people have difficulty about food especially fertilizer which has important part in agricultural production is a serious problem for Japan. While he investigate he discovered agricultural depression because of not meeting need of fertilizer. Therefore, he increased the area of study and learned that Japanese discovered a phosphate in a small island named Nauru and then offered to bomb there. 
When military authorities confirmed the information the island was bombed and agricultural production on Japan became paralyzed (Miman, 2007:55).

Cold War period began with the end of Second World War. In this period, economical competition among states flew away economical-technological level from political-military level (Nasheri, 2005:15). In two poled World that USA and Soviet Union lead the way, states began to carry out their economic relations in accordance with political preferences.

All intelligence and economical organization began to take over searching new roles and redefine themselves. Intelligence and opponent intelligence activities focused on military and political target in Cold War period. With the end of cold war nations began to carry out their local and foreign politics and programmers to enhance economical standards of citizens. In this case, economical superiority came into prominence and sort of espionage industry emerged in this field (Nasheri, 2005:19).

\section{ECONOMIC INTELLIGENCE AND MULTINATIONAL COMPANIES}

The term of multinational company began to appear in the stage of history especially after industrial revolution and making saving of individual with the right of private prosperity which liberalize and transferring savings to next generations revealed incorporation provided basis to gain strength. That kind of incorporations lived up to modern days. However, growing and for the use of sustainability of growing for spreading larger markets and transition different sectors from current sector have crucial importance for companies. In this period, multinational and multisectoral companies emerged and these began to have effect in politics and diplomacy and caused to development of activities known lobbying activities.

According to voluminous researchers maturation stage of multinational companies asserted as the most significant development run into the period after cold war. On literature, the first examples of these companies defined business which compete and invest to produce in foreign markets in different countries were built in America. West European and Japanese companies followed American companies (Seyidoğlu, 2003:581).

Economical changes emerge with globalization fact developed after cold war provided to expand markets of companies and multinational companies carried out their need of hold to market for sustainability of growing (Kazgan, 2000:34).

Increasing competition condition in international commerce, tension and conflicts which could be called almost as commerce war have begun to take past as a reason of wide enlightenment in economical fields. Each state tended towards to take biggest cut for their own company and to make it a main goal of foreign policy.

The most important states which made cold war period a history have sneakingly begun to commercial and economical war. These wars sometimes appear within International Trade Union, in European Union and even in ABD-AB relations (Girgin, 2003:171).

The year of 1990 had been a period in which changes began. Economic security took the place of ideological and military issues with the collapse of Soviet Union. 
Coming into season of competition in global commercial area has made companies compulsory to make investment for new inventions. Concentrating on AR-GE activities stands in central. This situation led companies to comprehend commercial as a war. Because capital is necessary for that must capital must more powerful with profits. Therefore companies give importance to have knowledge.

When economical dates began to play more important role in national security, there have been raise in economic intelligence activities as well. Economic espionage begin to make up new side of economic war. That espionage have globally become widespread. Economic espionage has ensured states to protect their economies and reveal technological competition.

Trillion dollars circulate in world trade have caused to budget much more for carrying out economical intelligence activities and protecting that. On the one hand, states and companies carry out these activities on other states and companies, at the same time, they try to be protected against activities of others. It could be said that practical implementations of economic intelligence is carried out by companies at the level of each company and state.

Businessmen who travel for economical meeting in 1992 were warned not to travel with French airlines revealing that French intelligence service bugged in seats (Potter, 1998:92). In these periods, China was warned by intelligence units that America, Canada and other developed countries which visit the country spy on economic intelligence activities.

It has occurred that there had been examples belong to person punished and met legal sanction while stealing commercial secrets. Understanding that Tokashi Okamoto stole DNA samples in clinic in 1998-1999 and confirmed that these samples had been used for medicines which cost millions dollars.

Horald Worden, old and retired worker of Codec Company was catch while stealing commercial secrets of Codec to China in 1997. Kenneth Branch and William Erksie, managers of Lockheed Martin company commentated to penalty fine, 850000 dollars and 15 years of prison by finding quality of stealing commercial rocket programmed which cost millions dollars.(Nasheri, 2005:144-153)

$\mathrm{CIA}$, American Intelligence Service, listened to interview of Rytura, minister of commerce, and businessmen of automotive sectors and transferred these information to American businessmen (Güldiken, 2006:179). In 2009 Starwood raised by employing 10 senior managers who worked ay Hilton before because managers took the significant documentaries with themselves while leaving from Hilton.

Larry Elison, manager of Oracle, did not hesitate to copy interface of Microsoft and committed design theft accepted as Industrial espionage. Steven Levis Davis received imprisonment for 27 months in 1998 and had to pay 1.3 million dollars for indemnity. His quilt was using commercial secret which he got in the period of Gillette company to use his own commercial rise. 
Expert who work as chief of production in Opel took the design dates with him and damaged Opel severely. Case which continues for 4 years ended up in 1997 and Volkswagen paid compensation for 100 million dollars to General Mobile, main loader of Opel, and signed contract for order of auto part cost 1 billion dollar. However, Volkswagen that still deny to apologize has made more profit of car soled than compensation.

As is seen of examples, economic intelligence activities are carried out in a wide range of companies to countries. Giving deferent punishment by taking legal measure to protect by these activities could be addressed helpful to identify legal ground of economic intelligence activities.

\section{EFFECTS OF ECONOMIC INTELLIGENCE}

Competition conditions rising in 21.century requires intelligence services to take idiosyncratic roles. It could be conferred that countries and intelligence services in which economic intelligence gathering activities take place on top have superiority in global. Therefore, location departments which will operate within intelligence service called are called for. Information by component constituted within intelligence service requires to include wide range from new mobile phone in China to memorandum report about financial collapse in Argentina.

Difficulty of keeping and protecting of monopoly of information in globalization world could be a good chance to acquire national investments and strategic technologies in which financial crisis spread out whole global markets. Because it will be difficult to protect such a information. International society is in struggle forming an economic system which is more liberal and more transparent. More complex economic policies, intellectual information's, worker right and foreign investments directly take part.

International system, changing conditions after Cold War, has revealed some important problems. What kind of concepts should economic security have and how should states react that? (Potter,1998:1). Recently, economic superiority has leashed more important position than military superiority. Nations that have economic superiority will be able to obtain military superiority and use it in every field. Providing economic intelligence security will be the first step for taking superiority.

It is indicated that the main thing that companies will need in future is getting true information about markets. Thus, companies and countries will be informed and make provisions about improvements in different field. Therefore, the need for intelligence has increased strongly (Pearce, 1976:117).

The right economy and competitive commercial improvement ability of nations in out world depend on utilizing of commercial activities and scientific and technologic norms. Information age of today require trade to be competitive in global and to share critical information with proper component and to be protected against opponents, supplier, customers and foreign countries while doing this. The obligatory of protecting possessed economic information requires identifying precaution about committing an offense and providing legal infrastructure. 
It can be said that the activities of getting information about the economic intelligence have tactic and strategic levels. The basic level is the studies of companies. The mid-level has been conducted by financial institutions and the companies that have improved the information technologies with the aim of capital movement and financial liberalization. The national level includes the studies and decision centers and appears in anonym political environments and especially Europe and Japan. The last level can be qualified as an international level. This level is used to form a strategically alliance by the multinational companies and to get international economic information's by the associations with two or more members like European Community (Potter, 1998:24).

The actors of economic fans from countries will have advantage against opponents with the economic intelligence system. Firstly, the information's from economic intelligence activities will be guiding documents to determine the states' economics politics. While the economic intelligence system is analyzed, it is essential to accept the existence of two different fields: government and company policy because the ongoing globalization requires that difference.

On the definition and practices of economic intelligence, three main factors are seen. The first one is the exportation of economic intelligence local information sources (Cole, 1997:23). The process of getting valuable information by analyzing and evaluating the obtained information begins with this factor. The second factor is that economic intelligence is different from economic espionage. This condition includes that some of the information is legal and the sources are free. The third factor in that economic intelligence is conducted in different steps of collection, sharing and evolution activities interactively by the big organizations. In operational level, economic intelligence can be considered as product and process. The product from economic intelligence is a useful information. The economic intelligence process is to acquire systematically, to evaluate and make the obtained information useful (Clerc, 1997:305).

National economic intelligence system of a country can be stated as the whole efforts and strategies of sharing among the different economic organizations in the country such as states, government entrepreneurs, education systems, commercial and professional organizations. It is mentioned that there have been three main goals. The first goal is to associate comment and comprehension abilities between economic and social factors in the country and to spread out these to the economy actors of that country. This aim can be explained as the use of the abilities by revealing the capacity of the country. The second aim is to evaluate the opportunities of globalization with harmonious attempts. It can be said the third aim is to carry out the strategic opportunities created by international markets and that will contribute to the country for providing economic and social development (Clerc, 1997:310).

The national system of each country is formed by their own cultural and historical accumulation. On analyzing the global progressing of economic relations during the past, it is clear that the countries giving importance to this field are also among the global actors. For instance; England, Japan, France, the USA and China, etc. 
The cultural structures and national ideological thinking systems of these countries provide them with the implementation of specific features. Thus, the way of success is opened the national synergy.

\section{CONCLUSION}

Effects of globalization on world has led countries to engage with each other more and made possible to become widespread and spread of usage of new knowledge and whole innovations. On that point, it is required to mention about transformation which economic progress face has made globalization to become more powerful. Then, economic progress in which agriculture dominate gave place to new progress in which industrial revolution and industrialization gain currency and improvement based on current information followed. Thus, the concept of industrialized country alleged as a goal has become a basement for economic development as protruded from the top level.

With the information and communication improvement, production, consumption and distribution relation which are main factors of economy and whole economic structure reorganized in the manner of taking information as the main factor and information has become the main factor of competition.

Manager of information decide to which way to move and how to take place in economic system. In this manner, global management of information has become the main source of economic and politic competition including technology. The role of improvements in information and communication technology in economic development has turned into the concept of knowledge economy a developing criterion for countries. Accordingly, countries will be able to reveal their goals to become a developed country by aiming to become knowledge economy. Transformation in economic structure with becoming a key of economic development of knowledge economy has directed policy makers to new searching's as well as pushed economy actors to change in this way.

With the end of Cold War, the question of what secret services, delegated for ideological fight for years, and experienced agents would do became a current issue. The answering of question did not take long. The new mission of secret services in new deal rising with globalization is contributing to protect and develop national economy. Because good/bad guys of new world order would be companies, trademarks and holdings now.

Economic intelligence activities have been carried out in wade economical range from companies to countries. New concepts like industry espionage technologic theft, and design theft have come into our lives with the development of technology. Stealing of information by using these kind of intelligence techniques could cause progress of collapse of economy of countries and go bankrupt of companies. Even legal statue is sufficient for claiming our rights; protecting our rights, preventing our company secrets to be at someone else, being careful about manager transferring and displaying sensitivity in many subjects could protect us from economy espionage which is one the most important threats of 21.century in nowadays in which information is a power. 


\section{REFERENCES}

AKAR, Atilla, (2005), Casuslar: Derin Savaşın Sıradışı Neferleri, Timaş Yayınları, İstanbul.

AKTAN, Coşkun Can ve Mehtap TUNÇ, (1998), “Bilgi Toplumu ve Türkiye”, Yeni Türkiye Dergisi, s.118-134.

AKTAN, Coşkun Can ve i. Y. Vural (2004), Yeni Ekonomi ve Yeni Rekabet, Türkiye İşveren Sendikaları Konfederasyonu, Ankara.

AVCı Gültekin, (2004), İstihbarat Teknikleri, Aktörleri, Örgütleri Ve Açmazları, Timaş Yayınları, İstanbul.

BARNETT, Michael L., (2006), "The Keystone Advantage: What the New Dynamics of Business Ecosystems Mean for Strategy, Innovation, and Sustainability", ISSN 1558-9080, Academy of Management Perspectives; Vol. 20- 2, pp. $88-90$

BASALLA, George, (2004), Teknolojinin Evrimi, Çev. Cem Soydemir, ISBN 975-403-047-2, TÜBiTAK, Ankara.

BAYRAM, H. (2010), Bilgi Toplumu ve Bilgi Yönetimi, Etap Yayınevi, İstanbul.

BRAUDEL Fernand (1991), Maddi Medeniyet ve Kapitalizm, Çev. Mustafa Özel, Ağaç Yayınları, İstanbul.

CLARKE, Matthew, (2003), e-Development? Development and New Economy, World Institute for Development Economics Research (WIDER) - Policy Brief No.7, United Nations UniXII. "Türkiye'de İnternet" Konferansı, Ankara 330 versity, ISBN 92-9190-573-9, Helsinki, 2003, http://www.wider.unu.edu/publications/pb7.pdf

CLERC Philippe, (1997), Economic Intelligence, Unesco Press.

COLE, Michelle, (1997), Proliferation of High Tech Firms Fosters Espionage, Idaho Statesman.

DENNING, P.J. ve Durham, N. (2001), The core of the third-wave professional. Communications of the ACM, 44(11): 21-25.

DRUCKER, P. F. (1994), Kapitalist Ötesi Toplum, (Çev: B. Çorakçı), İnkılap Kitapevi, İstanbul.

EĞRi Sadettin, (2012), "Hıtay Sefaretnamesi ve Kanunname-i Çin Ü Hıtya'da İpek Yolu İzlenimleri”, Turkish Studies, International Periodicals for The Languages, Literature and History of Turkish, Volume 7/2, 412.

ELIASON, Gunnar, (2005), "The Nature of Economic Change and Management in a New Knowledge Based Information Economy", Information Economics and Policy Vol. 17, pp. 428-456

FiALKA John, (1997), War By Other Means: Economic Espionage in America, New York, 45-46.

GiRGiN, Kemal, (2003), Modern İstihbarat ve Türkiye, Okumuş Adam Yayıncılık, İstanbul.

GÜLDiKEN Nevzat, (2006), “Bilginin Elde Edilmesi ve Korunmasında Ekonomik İstihbarat Sistemlerinin Rolü”,Cumhuriyet Üniversitesi İktisadi İdari Bilimler Dergisi, Cilt 7, Sayı 2, 174.

JEFFRES, L. W. (2007), “Media Technology and Civic Life, Communication Technology and Social Change: Theory and Implications", Ed. C. A. Lin ve D. J. Atkin, New Jersey: Lawrence Erlbaum Associates.

KAYMAS, S. (2010), "Yeni Liberalizmin Hegemonya Uğrağı Olarak Enformasyon Toplumu Söylemi ve Gelişmekte Olan Ülkeler: Türkiye ve Bilgi Toplumu Siyasası”, Yakındoğu Üniversitesi Sosyal Bilimler Dergisi, III(2), 64-104.

KAZGAN Gülten, (2000), Küreselleşme ve Ulus Devlet, Yeni Ekonomik Düzen, İstanbul Bilgi Üniversitesi Yayınları, İstanbul, 34.

KUHN, M. (2007), "Inside Global Learning Societies - The "War of Ideas" of the Good World in the Global Battle of Cultures", Ed. M. Kuhn, New Society Models for a New Millennium: The Learning Society in Europe and Beyond, New York: Peter Lang Publishing, 11-44.

KUTLU, E. (2000), Bilgi Toplumunda Kalkınma Stratejileri, Anadolu Üniversitesi İktisadi ve İdari Bilimler Fakültesi Yayınları, Eskişehir.

KUTLU, E. (2005), “Bilgi ve Kalkınma”, Ed. Muhsin Kar ve Sami Taban, İktisadi Kalkınmada Sosyal, Kültürel ve Siyasal Faktörlerin Rolü, Bursa: Ekin Kitabevi, 89-114. 
LEUNG, S. K. C. (2004), Statistics to Measure the Knowledge-Based Economy: The Case of Hong Kong, Wellington: 2004 Asia Pacific Technical Meeting on Information and Communication Technology (ICT) Statistics.

MANNING Martin, (2006), Economic Intelligence, Http://Www.Espionageinfo.Com/ Ec- Ep/EconomicIntelligence.Html.

MiMAN Ahmet Tarık, (2007), Küreselleşmenin Ordusu, Ekonomik istihbarat, IQ Kültür Sanat Yayıncılık, İstanbul, 55.

NASHERI Hedieh, (2005), Economic Espionage And Industrial Spying, Cambridge University Press, United Kingdom.

OGAN, C. (2007), "Communication Technology and Global Change, Communication Technology and Social Change: Theory and Implications", Ed. C. A. Lin ve D. J. Atkin, New Jersey: Lawrence Erlbaum Associates.

ÖZSAĞıR, A. (2007), Bilgi Ekonomisi, Nobel Yayın Dağııım,. Ankara.

PEARCE F.T., (1976), Business "Intelligence Systems: The Need, Development, And Integration", Industrial Marketing Management, Elseiver Scientific Publishing, Amsterdam.

PORTEOUS Samuel D., (1995), Economic Espionage: New Target For CsIs, Canadian Business Review 20.

POTTER, Evan H., (1998), Economic Intelligence \& National Security, Carleton University Press, Canada.

RiFKiN, J. (2000), The age of access: how the shift from ownership to access is transforming modern life. London: Penguin Books.

SEYiDOĞLU Halil, (2003), Uluslararası Iktisat, Teori Politika ve Uygulama, Güzem Cab Yayınları, 15. Baskı, İstanbul, 581.

SMiтH, K. (2000), What is the Knowledge Economy? Knowledge-Intensive Industries and Distributed Knowledge Bases, Norway: DRUID Summer Conference on The Learning Economy - Firms, Regions and Nation Specific Institutions.

SÖYLEMEZ, Alev, (2006), "Bilgi Ekonomisi", V inci Uluslararası Bilgi, Ekonomi ve Yönetim Kongresi, Kocaeli, http://iibf.kou.edu.tr/beykon

SPLiCHAL, S. (1994), "From Civil Society to Information Society", Ed. S. Splichal, A. Calabrese ve C. Sparks, Information Society and Civil Society, West Lafeyette: Purdue University Pres, 50-77.

STEVENSON, N. (2003). Cultural citizenship: Cosmopolitan questions. Berkshire, England: Open University Press.

STIGLITZ, Joseph E., (1999), "Public Policy for a Knowledge Economy", The World Bank, London, http://www.worldbank.org/ html/extdr/extme/knowledge-economy.pdf

TOFFLER, Alvin, (1992), Yeni Güçler Yeni Şoklar, (Çev:B. Çorapçı), Altın Kitaplar, İstanbul.

WiLLiAMS Benjamin H., (1954), Economic Intelligence and Economic Walfare, Industrial College of The Armed Forces, Washington DC, 12.

YILDIZHAN Cengiz, (2005), VII-X. Yüzyıllarda İpek Yolu Ticaretinin Türk Tarihine Etkileri, Mimar Sinan Güzel Sanatlar Üniversitesi Sosyal Bilimler Enstitüsü, Yayınlanmamış Yüksek Lisans Tezi, İstanbul, 19. 